\title{
Genealogia Genética e o potencial reatar de laços transtemporais
}

\author{
Genetic genealogy and the potential to reconnect transtemporal ties \\ Genealogía genética y el potencial para reconectar lazos transtemporales
}

Recebido: 27/01/2022 | Revisado: 31/01/2022 | Aceito: 02/02/2022 | Publicado: 05/02/2022

Thiago Maia Sayão de Moraes ORCID: https://orcid.org/0000-0002-7132-1771

Universidade Federal de Goiás, Brasil E-mail: thiagomsayao@gmail.com

Ludimila Poirier

ORCID: https://orcid.org/0000-0003-0373-2023 Faculdade de Direito/Universidade de Coimbra, Portugal E-mail: ludimilapoirier-58745C@adv.oa.pt

Rosane Alves de Abreu

ORCID: https://orcid.org/0000-0003-4332-7508 Instituto Federal de Educação, Ciência e Tecnologia de Mato Grosso, Brasil E-mail: rosane.abreu@ifmt.edu.br

Douglas de Souza Rodrigues

ORCID: https://orcid.org/0000-0001-7473-7425 Universidade Federal Fluminense, Brasil E-mail: rodriguesdouglas@id.uff.br

Tayza Codina de Souza Medeiros Guedes ORCID: https://orcid.org/0000-0002-4537-6947 Instituto Federal de Educação, Ciência e Tecnologia de Mato Grosso, Brasil E-mail: tayza.codina@ifmt.edu.br

Raul Tavares Cecatto

ORCID: https://orcid.org/0000-0001-9310-0518 Instituto Federal de Educação, Ciência e Tecnologia de Mato Grosso, Brasil

E-mail: raul.cecatto@estudante.ifmt.edu.br

\begin{abstract}
Resumo
A pesquisa genealógica tem sido impactada com a recente aceleração no ritmo das mudanças, sobretudo graças à contribuição vinda da genética por meio dos testes de ancestralidade. Os resultados desse impacto reverberam em novas dimensões da genealogia tanto ancestral como parental em paralelo aos impactos severos na instituição família. O caráter perene da ligação familiar, que mesmo a despeito da diversidade de laços familiares, assenta na parentalidade a qualidade de fenômeno quase atemporal e absolutamente universal, recebe a valiosa contribuição da pesquisa genética e antropológica. O presente estudo apanha os recentes incrementos dos estudos de genealogia genética e instituição familiar potencializados por pesquisas genéticas relativas à saúde refletido à luz do Direito fomentando caminhos para a parentalidade e identidade diante dessa reconstrução social de dimensões do ser-nomundo. Assim, apresenta-se o desvelar da ancestralidade remota que possibilita novos encontros e construções familiares e parentais incluindo ações públicas brasileiras que podem potencializar esses resultados como política pública estruturada.
\end{abstract}

Palavras-chave: Genealogia; Genética; Ancestralidade.

\begin{abstract}
Genealogical research has been impacted by the recent acceleration in the pace of change, mainly thanks to the contribution coming from genetics through ancestry testing. The results of this impact reverberate in new dimensions of both ancestral and parental genealogy in parallel with severe impacts on the institution of family. The perennial character of the family bond, which even despite the diversity of family ties, seats in parenthood the quality of an almost timeless and absolutely universal phenomenon, receives the valuable contribution of genetic and athropological research. The present study catches the recent increments in genetics and institution family by genetics related to health, reflected in the light of Law, promoting ways for parenting and identity in the face of this definition of studies of social dimensions of being-in-the-world. Thus, it presents the remote unveiling that enables new family and parental encounters and constructions, including Brazilian public actions that can enhance these results as a structured public policy.
\end{abstract}

Keywords: Genealogy; Genetics; Ancestry. 


\section{Resumen}

La investigación genealógica se ha visto afectada por la reciente aceleración en la tasa de cambio, especialmente gracias a la contribución de la genética proveniente de dos pruebas de ascendencia. Los resultados de su impacto repercutieron en nuevas dimensiones de la genealogía ancestral y parental en paralelo a los severos impactos en la institución familiar. La continuidad del vínculo familiar, que a pesar de la diversidad de los lazos familiares, establece la crianza como un fenómeno atemporal y absolutamente universal, recibe un valioso aporte de la investigación genética y antropológica. El presente estudio engloba las recientes incorporaciones a dos estudios de genealogía genética e institución familiar apalancados en investigaciones genéticas relacionadas con la salud reflejadas a la luz del derecho, promoviendo caminos hacia la crianza y la identidad a la luz de esta reconstrucción social de las dimensiones del ser-no-mundo. Del mismo modo, aparece o revela la ancestralidad remota que permite nuevos encuentros y construcciones de familias y padres, incluyendo acciones públicas brasileñas que pueden potenciar estos resultados como política pública estructurada.

Palabras clave: Genealogía; Genética; Ascendencia.

\section{Introdução}

A genealogia está presente na história humana desde tempos remotos, conforme relatos bíblicos, nas obras de Homero e antigos registros egípcios; no entanto esse resgate ao passado tem ganhado novas dimensões diante da acachapante revolução da civilização apontada pelo seminal futurologista Alvin Toffler (1980). Esses avanços revolucionários consolidados e potencializados no setor da genética pelo mapeamento de genoma humano em 2003 oportunizaram a recente popularização de testes de ancestralidade (Duster, 2014; Marchesini Stival, 2020) rompendo os limites preexistentes da pesquisa genealógica. Este estudo reflete dimensões derivadas do significado de ser-no-mundo com uma investigação genética-genealógica marcada por esse rompimento.

Alvin Toffler (1980), notando a tendência pessimista e desesperadora diante de possibilidades catastróficas para a história humana - como guerras, desastres tecnológicos, ou econômicos, entre outros - percebe que representam, em paralelo, fascinantes potenciais - atrelados a novas formas de vida familiar, avançados métodos de produção, entre outros demonstrando que em meio a um período de transição tormentoso e inçado de crises o eldorado se apresentara formando uma sociedade mais decente, democrática, sensata e suportável. Nesse sentido, justifica-se os graves impactos, bem como a noção de que esse processo de transição se assemelha à metáfora por ele proposta: de uma nova onda, forte e implacável - a do conhecimento - defronta-se com o repuxo da onda anterior, que perde força a cada dia - a da industrialização. Assim, e ainda nessa prospecção certeira, apresenta-se a ruptura familiar ora indicada e evidentemente modificada se comparada à estrutura legitimada por tantos séculos (Bauman, 2001).

A família, responsável pela origem da realidade que constitui as relações humanas (Lacan, 2008), é o objeto, posto em perspectiva histórica, da genealogia. No entanto, sua importância na concepção do ser remete pela própria etimologia da palavra, derivada de famulus - escravo doméstico - carregando em seu âmago a servidão (Engels, 1884) como reflexo de todos os antagonismos desenvolvidos na sociedade moderna e indicada por Toffler (Toffler, 1980) como fadada ao fracasso e nova constituição. Aproveitando a popularização dos testes de ancestralidade esse contexto de turbulência não é participado pela pesquisa genealógica.

A pesquisa genealógica, que consolida biografias de origens familiares desde as imediatas até as mais remotas, vem, na esteira dos avanços tecnológicos, demandando por ferramentas para gestão de registros genealógicos. Esses esforços vêm sendo encabeçados pela Igreja de Jesus Cristo dos Últimos Dias que cataloga e sistematiza registros genealógicos desde 1894, disponibilizando a qualquer usuário uma plataforma on-line de gestão genealógica de referência mundial, tanto em gestão genealógica como em biblioteconomia e ciência da informação - chamada Family Search. A partir dele, e em conjunto com empresas de testagem de ancestralidade e plataformas de gestão de informações genéticas e genealógicas pesquisadores têm gerido dados revelando uma potente ferramenta de fomento à essa identidade genealógica. 
Qual o potencial dessa revolução na família e como isso pode se desdobrar nela com mapeamento genético? Essas questões tratadas em sequência pelas seguintes seções: (a) Fundamentos do Teste de Ancestralidade - que apresenta meticulosamente a sistemática do teste de ancestralidade, contribuindo para traçar; (b) Perspectivas de Família em Genealogia - que concatena o significado de ser-na-família e ser-no-mundo diante dos horizontes da genealogia genética; (c) A legitimidade e o Institucionalismo familiar - cuja a pietra d'angolo é o parentesco e a filiação; (d) Considerações Finais consolida os apontamentos referenciados para o futuro com a leitura hodierna no que tange a genealogia genética. Portanto, apresenta-se uma seletiva e articulada literatura enfocando o caráter transdisciplinar que lhe é próprio.

\section{Fundamentos de Testes de Ancestralidade}

O mistério da criação humana teve uma importante página revelada com a conclusão do mapeamento genômico humano, em 2003. Através dele foi possível identificar a estrutura da construção de trilhões de células formadas a partir de uma única célula originária que contém o DNA (ácido desoxirribonucleico), responsável por armazenar toda essa informação genética. A combinação de apenas uma pequenina fatia $(0,1 \%)$ desse DNA é variável entre os seres humanos e é dela que se constituem as características individuais humanas (Canal USP, 2020).

Essas combinações vêm sendo correlacionadas a predisposições de saúde com potencial impacto no seu tratamento, motivando grandes países a mapearem o genoma de suas populações, para otimizar recursos nessa área - já que este perfil pode ser identificado com base na ancestralidade (Escobar, 2019). Portanto, os testes de ancestralidade - que representam mapeamento de pequeno percentual do genoma - tornaram-se possíveis com essa identificação de perfis genéticos.

No entanto, esses testes dependem de um esforço transdisciplinar no sentido de vislumbrar migrações cruciais à identificação ancestral. Para tanto, estudos recentes de linguística, biologia, antropologia e arqueologia juntamente com o mapeamento do DNA humano conferindo maior compreensão acerca das migrações e dos agrupamentos genéticos remotos (Fabrício R. Santos, 2016; Souza, 2011). Desse modo, os testes de ancestralidade partem da análise comparativa do DNA coletado com milhares de outras amostras de nativos correspondentes à diversos agrupamentos étnicos de todo o globo. Essa comparação, que pode ser feita através de plataformas além da contratada para mapear o DNA do indivíduo, leva também em conta características de marcadores genéticos uniparentais -transmitidos ao longo das gerações sem influência de recombinação. Desse modo é possível retomar a linhagens mais remotas: pelo lado materno através do DNA mitocondrial passado pela mãe para os filhos e filhas; bem como a linhagem paterna pelo cromossomo Y - passado pelo pai apenas para os filhos homens (Fabricio R Santos et al., 1996); conforme Figura 1 a seguir. 
Figura 1 - Esquema de sucessão genética por cromossomo

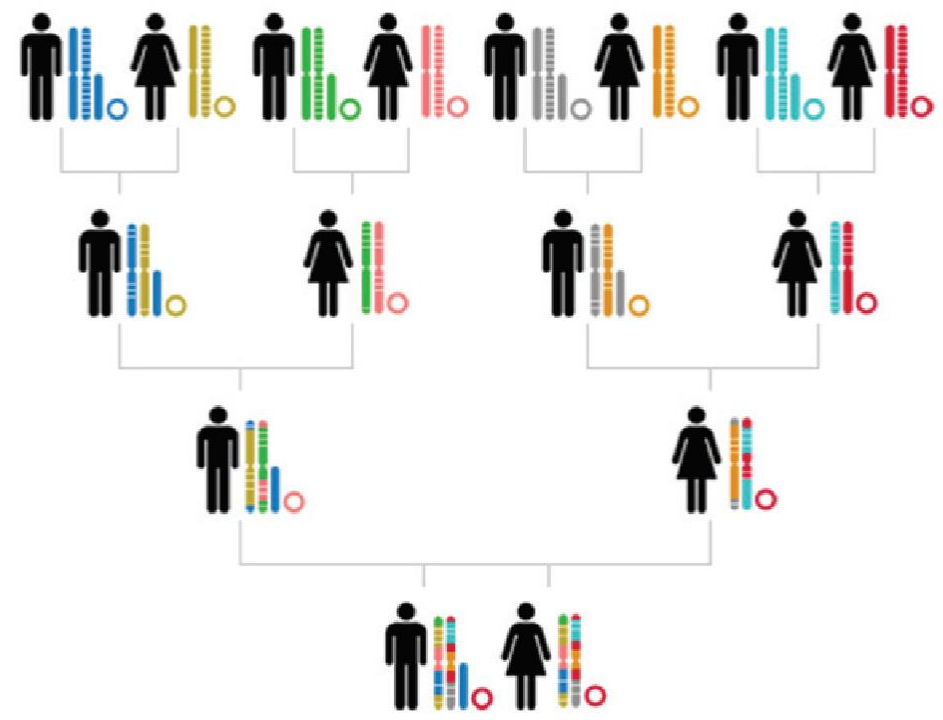

Fonte: Santos, (2016).

A Figura 1 extraída de Santos (Santos, 2016, p. 104), representa:

"Herança cromossômica através de quatro gerações: estão ressaltados os marcadores biparentais (pares cromossômicos maiores encontrados em homens e mulheres), uniparentais paternos (cromossomo Y que é menor e encontrado somente nos homens) e maternos (DNA mitocondrial, representado por um círculo e é encontrado nos homens e mulheres, mas herdados apenas das mães). Os autossomos (cromossomos biparentais maiores) podem sofrer recombinação a cada geração, ilustrados aqui com diferentes cores definidas na geração dos bisavôs. A geração atual (filho e filha) apresentam autossomos compostos de fragmentos de diferentes cores, que representam a recombinação entre cada par autossômico (cromossomos 1 ao 22) a cada geração. O cromossomo Y e o DNA mitocondrial são herdados de apenas um dos pais (pai e mãe, respectivamente) em cada geração, sem recombinação. "

Com o mapeamento dessa testagem é possível encontrar tanto parentes testados como também identificar agrupamentos genéticos remotos que foram conceituados como haplogrupos - um tipo de estrutura formadas por conjuntos de marcadores genéticos que são herdados em conjunto - fundamentais no estudo do DNA mitocondrial e do cromossomo Y (Costa, 2011). Portanto, concatena-se o estudo multidisciplinar norteado pelo detalhamento genético que estimando as origens dos haplogrupos identifica seus processos migratórios.

Nessa perspectiva familiar ${ }^{1}$, mais explorada na seção a seguir vincula essas informações de valor histórico e genealógico com a busca parental, já que as plataformas de coleta e análise de dados permitem que seus usuários interajam com seus correspondentes genéticos, possibilitando com isso o rastreio e identificação de ramos, e, por conseguinte, pais ou filhos não conhecidos. No entanto, outra série de variados benefícios pode ser coletada com os testes de ancestralidade, de cunho histórico e saúde, por exemplo.

\footnotetext{
${ }^{1}$ A pesquisa genealógica é fundamental para fazer coincidir a verdade biológica com a verdade jurídica, considerando-se que a família é intemporal e universal, mas também é um fenômeno polimórfico: se esse conceito é difícil de definir, é porque abrange realidades extremamente diversas. Em primeiro lugar, vale ressaltar que as comunidades familiares são fortemente disseminadas e diversas: elas diferem tanto em sua composição quanto em estrutura. Mas também deve-se observar que os laços que atam os membros da comunidade familiar uns aos outros são eles mesmos extremamente variados: note-se que eles podem resultar de parentesco, casamento ou a existência de convivência. Além da diversidade de grupos, há também a diversidade de vínculos. Cfr. Garrigue, Jean. Droit de la famille. Dalloz, 2. ed., Paris, 2018, p. 7 e ss.
} 
Por isso, no Brasil vem sendo desenvolvido o projeto DNA do Brasil (DNABr) que visa mapear e analisar o perfil genético de seu povo - que é significativamente diverso se comparado a outros países, apresentando-se como um modelo antecipado das mudanças demográficas na América do Norte e Europa (Patrinos et al., 2020). Esses autores, apontam o potencial para a medicina genômica a partir desse mapeamento que foi incorporado ao Programa Nacional de Genômica e Saúde de Precisão instituído pelo Ministério da Saúde pela Portaria nº1.949 (Ministério da Saúde, 2020) cujo objetivo é mapear em quatro anos o genoma de 100 mil brasileiros portadores de doenças raras, cardíacas, câncer e infectocontagiosas, como a covid-19 num investimento de $\mathrm{R} \$ 600$ milhões.

Através de mapeamento preliminar, realizado pelo DNABr foi possível confirmar e quantificar faces da história do Brasil trazendo uma nova dimensão do papel de homens e mulheres em sua construção. Estudos indicaram a prevalência do DNA mitocondrial brasileiro associado em sua maioria a origem de seus povos originários ou escravizados ao passo que o yDNA associa-se em sua maioria a origem europeia (Silva et al., 2020; Mendes et al., 2020). Diversos outros estudos acerca dos testes de ancestralidade vêm sendo analisados oferecendo perspectivas diversas de seus desdobramentos.

Concordando com Toffler (1980) e Bauman (2001) no sentido revolucionário que está sendo atravessado trazendo o contexto familiar Gaspar Neto (Gaspar Neto et al., 2011, p. 24) destaca sobre a ancestralidade que as "similitudes e diferenças genéticas" oriundas dos testes se tornam "indicadores de aproximação e distanciamento, inserindo as pessoas em uma cartografia que ao mesmo tempo desafia e redefine os limites do tempo e do espaço", ainda que desconfie da acurácia dos testes. Já Marchesini Stival (2020) destaca a importância de aconselhamento prévio, regulação e sensibilização sobre esses testes de ancestralidade, sobretudo pelas implicações potenciais sobre quem se submete e eles, bem como em relação aos que compartilham material genético com a pessoa testada. Nesse sentido Neves (2020) analisa as matérias veiculadas no jornalismo brasileiro sobre esse tema não apontam para as fragilidades dos testes, já que cada empresa gera os resultados a partir de seu banco de dados; e, além disso, não dão atenção às preocupações em relação à segurança de dados ou uso, tanto por parte do governo como por empresas de saúde.

\section{Perspectivas de Família em Genealogia}

A primeira instituição social do homem - a família - pode ser entendida como a responsável por inicia-lo na vida comunitária (Siep, 2016). Nessa construção Hegel traz como primeiro passo ético o casamento - pelo caráter livre das vontades de duas pessoas que objetivam se reconhecerem como unidade - demonstrando o símbolo valoroso da família. Portanto, a família está imbricada no homem enquanto indivíduo, fundamentando-o.

O ser humano, na sua natural curiosidade, olhando para dentro de si, busca se reconhecer, e diante disso, passa por um processo de olhar para o mundo, para a sua própria realidade. Se esse indivíduo se entende enquanto ser-no-mundo, dotado de passado e presente que impulsiona, projeta para o futuro, a família é um fato desse entendimento. Logo, se abrir para as possibilidades de si mesmo (ser-no-mundo) terá um fio familiar (ser família-no-mundo) para entrelaçar essa teia que é ser humano (Heidegger, 2007).

Com isso, a família alicerça a noção de pertencimento (Engels, 1884). Com isso, a testagem de ancestralidade segue crescente nos últimos anos (Gaspar Neto \& Santos, 2011; Neves, 2020), ainda que as famílias já tenham migrado para novos formatos - indivíduos vivendo sozinhos, ou em famílias reconfiguradas do tradicional pai-mãe-filhos - sinalizando que a busca pela ancestralidade não parece depender do formato tradicional. Essa busca pode ser uma alternativa à crescente fragilidade emocional que encaminha o sistema familiar até um ponto de irreconhecimento (Toffler, 1980); processo esse intensificado com efeitos da covid-19, sobretudo no Brasil, que é o mais sofre de solidão entre os 23 países analisados (Ipsos, 2021). 
Esse processo de testagem ancestral associa-se à genealogia também por meio do amplo esforço da Igreja dos Santos dos Últimos dias, que desenvolveu o Family Search - maior organização e sistema genealógico do mundo; uma referência em inovação, organização e disponibilização tanto para a biblioteconomia como para ciência de informação (Araújo, 2017). A ampla base de dados desse sistema interage com outras plataformas de gestão genealógica ${ }^{2}$, como também com órgãos públicos correlatos ${ }^{3}$, para capturar e microfilmar e preservar seus registros. Portanto, juntamente a esse notório sistema de informação o universo de genealogistas brasileiros, organizados em diversos institutos genealógicos - notadamente o Colégio Brasileiro de Genealogia e a Associação Brasileira de Pesquisadores de História e Genealogia - ou individualmente que por afinidade e buscando correspondência genética com a tradicional pesquisa genealógica, participam significativamente desses testes.

Além desses há dois outros típicos perfis de consumo de testes: o de genética recreativa - associada mais puramente à sua identidade familiar - sem desdobramentos em pesquisas paralelas; e o de busca parental - uma espécie pesquisa genealógica que aborda a história recente do indivíduo. Desses perfis destaca-se a correlação entre dois: o do perfil típico genealogista, que associa o teste de ancestralidade ao encontro de informações ancestrais e o que busca encontrar seu pai, mãe ou filho. O típico e ampliado arcabouço de pesquisadores genealógicos tradicionais pode impactar em uma importante contribuição na busca parental; isso porque um conjunto de coincidências genéticas encontradas entre o buscador parental e perfis identificados na genealogia tradicional facilita a identificação do ramo, e consequentemente do parente buscado. Diante desse importante problema o Conselho Nacional de Justiça (CNJ) resolve por meio do Provimento $\mathrm{n}^{\circ} 12$ tratar a busca parental ao constatar o insignificante número de averiguações de paternidade ante os quase 5 milhões de alunos sem informação acerca de sua paternidade identificados no Censo Escolar de 2009 (Conselho Nacional de Justiça, 2010).

Desse modo, o CNJ institui o Projeto Pai Presente, desdobrado de seu Provimento $\mathrm{n}^{\circ} 12$ estendendo a tratativa a qualquer filho registrado sem nome do pai, a partir da notificação de cada mãe para, querendo, informe os dados do suposto pai (MPPR, 2021). O processo segue de forma extrajudicial disponibilizando a testagem por teste de DNA, possibilitando inclusive a inclusão do nome do pai que voluntariamente pode reconhecer a paternidade. Apenas em caso negativo abre-se o precedente de judicialização, via ministério público. Ainda que a implementação do projeto tenha apresentado eficácia, seus resultados não indicam homogeneidade proporcional na participação por Estado; reforçando a importância de fortalecimento de sua implementação.

Em paralelo, mapeia-se a construção familiar contemporânea, ora apontada como irreconhecível por Toffler (1980), Bauman (2001) identifica motivos suficientes para sua quase dissolução. A incerteza do presente torna-se uma potente força individualizadora, capaz de diluir o espírito de solidariedade. Esse movimento, reverbera no enfraquecimento do casamento, enquanto acordo de dependência mútua, dando lugar à coabitação, com uma noção mais transitória. A instituição familiar, portanto, ganha novas perspectivas cuja legitimação precisa ser analisada em face dessa reconfiguração familiar e de novas possibilidades com os testes de ancestralidade.

\section{A Legitimidade e o Institucionalismo Familiar}

A família não permite de todo uma definição estrita quanto ao conceito em si, mas passa por uma noção sutil que leva quase que intuitivamente à ideia de que a família é importante. Essa noção é explicada porque resta um sentido de perenidade:

\footnotetext{
${ }^{2}$ Como o MyHeritage, Ancestry, Legacy.

${ }^{3}$ Como no caso brasileiro, de parcerias estabelecidas com o Tribunal de Justiça do Rio Grande do Sul ((Tribunal de Justiça do Rio Grande do Sul, 2008), Arquivo Nacional (Arquivo Nacional, 2009) e o Arquivo Público do Estado de São Paulo (Governo do Estado de São Paulo, 2015).
} 
a família existe há muito tempo e em todos os continentes, e mesmo que perdurável, não é de todo imutável, variando de forma, função e objetivos através dos tempos.

O fenômeno familiar é permeável às alterações sociais, e não obstante as mudanças que implicam também na estrutura atual da família, a antropologia revela que o humano é um ser familiar. Para Diogo Leite de Campos, a natureza da família reside basicamente na capacidade de amor de todos os seus membros. O autor leciona que é o amor o fator determinante da vida comum. Daí então que o mesmo afirma que a família poderá ser definida como grupo interindividual ${ }^{4}$, fundada no amor e na solidariedade (Campos et al., 2018).

Ainda que assim seja, as relações de família são sobretudo relações de parentesco e dentre as quais, as relações de filiação são indubitavelmente as relações de parentesco mais relevantes (Coelho et al., 2015). E à exceção das regras que concernem à adoção, o parentesco é uma relação de sangue, que significa a existência e prevalência de laços sanguíneos, principalmente porque a fonte do parentesco é a procriação; de modo que haverá parentesco, se houver consanguinidade, desobrigado haver ou não casamento entre os progenitores (Campos, 2004).

A filiação, destacada como relação de parentesco de maior importância, o é também, porque a partir desta é que podem ser extraídos os efeitos das responsabilidades parentais. E ao tratar a parentalidade como novo paradigma da família contemporânea, Dominique Fenouillet afirmou que é preciso compreender também a multiplicação da ocorrência do tema da parentalidade no discurso jurídico atual, e sempre no sentido de questionar o fenômeno, já que a análise teórica revela por exemplo que a instituição familiar e o parentesco são constantemente postos à prova, à causa da permeabilidade do fenômeno familiar já citada (Fenouillet, 2014). Assim considerado, pode-se afirmar que o crescente sucesso da parentalidade no discurso legal é justificado pelas tentativas de melhor percepção do tema, o que inclui questões de procriação, já que a procriação como facto natural nem sempre corresponderá à filiação como facto jurídico, porque a verdade jurídica nem sempre coincide com a verdade biológica.

Maria Berenice Dias aponta um tendente processo de desbiologização da paternidade e da maternidade, e para a autora a socioafetividade abarcará toda relação de paternidade, podendo ter origem biológica ou não (Dias, 2013). Entretanto, existem estados, como por exemplo a França e Portugal, nos quais o legislador foi mais propenso a fazer coincidir a verdade biológica com a verdade jurídica, e estas, com a verdade sociológica (psicológica e afetiva), sempre que possível, sem perder de vista a salvaguarda do real interesse dos filhos (Santos, 1999).

Trata-se do Princípio do respeito pela verdade biológica, que acolhe a ideia de que para estabelecer a filiação, os vínculos jurídicos devem ser correspondentes aos vínculos biológicos. O que o princípio consagra é o justo entendimento de que as normas regentes do reconhecimento dos vínculos devem produzir um resultado jurídico fiel à realidade biológica, de maneira a evitar que sejam pais jurídicos pessoas que não foram progenitoras do filho. O princípio do respeito pela verdade biológica é o instituto que justifica por exemplo, a utilização de meios jurídicos de correção, quando a aplicação das normas do estabelecimento da filiação não tenha permitido a correspondência da maternidade ou paternidade biológica. Guilherme de Oliveira aponta sabiamente que é conhecido que em outros sistemas jurídicos, a realidade biológica não tenha o mesmo valor

\footnotetext{
${ }^{4}$ Importa referir que o "ser" da pessoa pode ser tido como um "ser" relacional, que é tanto um "ser com outros" como "ser com os outros", no sentido de que o que atinge estes, poderá vir a atingir outras pessoas. Diogo Leite de Campos trata da génese dos Direitos das Pessoas, e observa que os Direitos da Personalidade em sentido estrito visam a proteção da pessoa em si mesma, como ser não-social; "direitos de 'direito civil' por se ocuparem da pessoa livre de constrangimentos sociais, autónoma. Da pessoa como autónoma criadora de si própria. Direitos contra os outros, contra os grupos, contra o Estado.", contudo o autor aponta que os direitos da personalidade em sentido lato, compreendem a actividade de inter-relacionamento da pessoa, "a sua dimensão social, a pessoa-ser-social", que são designados pelo doutrinador como "direitos da pessoa autónoma, mas colaborante, criadora do espaço social e político". Em última análise, aponta que "a pessoa não 'existe' senão com-os-outros, pressuposto e referência da sua humanidade.” Cfr. DiOGo LeITE DE CAMPOS, Nós: estudos sobre o direito das pessoas, Coimbra, Almedina, 2004, p.15 e ss.
} 
capaz de se sobrepor às demais, porque este não é o único interesse que merece respeito, considerando-se igualmente os laços afetivos e culturais. Porém, nos países citados (Portugal e França), o princípio do respeito pela verdade biológica é um princípio estruturante do direito de filiação (Oliveira, 2018).

Explica-se por exemplo, que se duas pessoas pertencem à mesma família, muitas vezes é porque estão unidas por um laço de parentesco. A criança que vem ao mundo está, portanto, destinada a ser acolhida e criada por uma mãe e um pai. No entanto, quando sua ascendência é estabelecida em relação a esta mulher e a este homem, ela não apenas relaciona-a com estes dois indivíduos: ela também relaciona-a com estes, e a criança passa a fazer parte da família de cada um deles. Fazer parte da família de cada um dos progenitores permite que a criança passe a ser membro de duas tribos, e a esta criança é ofertada a oportunidade de relacionar-se também com irmãos e irmãs, avós, tios, tias, primos e antepassados mais distantes (Garrigue, 2018), que é o que representa essa grande diversidade dos laços interindividuais.

No que cinge à própria determinação dos laços, como explicado, a família contemporânea baseia-se nos laços familiares que a lei tem recebido há muitos séculos, mas também acolhe laços que surgiram mais recentemente, dos quais nem sempre se sabe se são por lei ou de fato, ou ainda apenas um apego interindividual ou um vínculo familiar genuíno. O que significa dizer que a família é tradicionalmente formada em duas ordens: na ordem vertical, baseia-se em um vínculo elementar, o vínculo parental e em ordem horizontal, associa aliados e assimilados e baseia-se principalmente em um vínculo elementar de parentalidade, que hoje geralmente liga o indivíduo aos seus autores biológicos. Em ambos os casos é um elo de paternidade e maternidade, que inscreve o sujeito em uma ordem genealógica (Fenouillet, 2014).

Da numerosa quantidade de funções destacáveis da instituição familiar, desde a função antropológica, ligada à própria condição humana, passando pela função econômica (função de produção econômica se considerada a família a primeira célula de consumo), a função social, na qualidade de fonte primeira de solidariedade, existem questões coletivas e individuais subjacentes, visto que tais funções dão à família uma importância proeminente, tanto para o indivíduo quanto para o grupo.

A família é um lugar insubstituível para o sujeito, que o inscreve no tempo e no espaço e insere em um grupo humano a priori benevolente. Mas também é, em mais de uma forma, um apoio essencial para o Estado, por exemplo, evitando o fardo dos mais frágeis (veja-se a obrigação de prestar alimentos, por exemplo), garantindo a educação dos filhos menores, dentre outros. E também torna-se um refúgio onde todos têm a certeza de encontrar intimidade, solidariedade, particularismo. Essa função libertadora e protetora, mal medida em tempos de paz, é totalmente aberta nas horas sombrias de um país: ditadura, guerra, cataclismo natural - com no caso da covid. A evolução do Direito, no entanto, parece ser inspirada no fenômeno sociológico, descrito por Durkheim, do contínuo encolhimento da família (Fenouillet, 2014). A propósito de tal "encolhimento", é questão que talvez possa ser revertida através do cerne do presente trabalho, qual seja, o propósito dos avanços na área da pesquisa genealógica da ancestralidade.

\section{Considerações Finais}

Esse estudo recortado para a genealogia evidencia uma revisitação ao passado para enfrentar os desafios vindouros já indicados pelo distinto futurologista Alvin Toffler há mais de 40 anos. Chama a atenção a concretude e mazelas dessa revolução - tão presentes e surpreendentes para a atualidade - terem sido vislumbradas com tamanho detalhamento por um texto escrito há tanto tempo. Parece que a imersão nessas mazelas impede de compreender seu processo e completude: passos para o passado para compreender o presente e inspirar para o futuro.

Os testes de ancestralidade representam parte disruptiva dessa revolução, com resultados potencializáveis no enlace com a busca parental bem como na saúde e história. Em questões de saúde, já é notório o potencial de incremento a partir da 
análise e tratativa dos dados, como citado brevemente. Novas perspectivas históricas emblemáticas também se confirmam, como a maior prevalência no Brasil de DNA não europeu pela linha mitocondrial (feminina) do que no y-DNA; sinalizando potencial desdobramento a partir de uma análise mais ampla e esmiuçada podendo traçar inclusive perfis genéticos mais ancestrais dos imigrantes no Brasil. No entanto, ainda que seja uma realidade, a consequência de quaisquer de seus desdobramentos deve ser minuciosamente analisada, não somente no âmbito sociológico, de segurança de dados e de saúde apontados aqui, como também em sua regulação.

$\mathrm{Na}$ dimensão genealógica, sinaliza para uma contribuição exponencial em sua construção à medida que o teste vai se popularizando. Isso porque um teste poderá contribuir para o enlace de várias construções genealógica, com exponencialidade até chegar a um nível de saturação. Estudos quantitativos nesse sentido poderão indicar a otimização de recursos, ao agregar a inserção desses testes como política pública ventilada mais a seguir.

A dimensão de identidade e pertencimento, quanto a testes de paternidade e maternidade tende a contribuir proporcionalmente ao envolvimento de genealogistas nessa causa, podendo ser ampliada ainda mais com incentivo à testagem dos que não possuem pais identificados. Nesse sentido uma múltipla agenda é sugestionada nos seguintes âmbitos e objetivos: (a) pesquisa - a fim de esboçar um desenho de política pública que aproveite essa oportunidade de tecnologia afim de dirimir o grave problema social da "falta de paternidade"; (b) de política executiva pública - de apoio à pesquisa bem como à destinação de recursos atinentes à sua execução, seja por meio do oferecimento do teste aos que não possuem o/os pai/mãe/pais no registro e tampouco tenham conhecimento de quem seja, ou ainda por meio de apoio à entidades genealógicas e/ou genealogistas que contribuam para esta busca; (c) legislativa - de apoio no sentido de facilitar o processo de testagem em entes que se revelem oportunos para o processo de identificação do pai, cogitando para tanto a disponibilização dos trechos de coincidência de DNA entre o interessado e a pessoa identificada com o perfil oportuno para este fim.

Existe um brocardo jurídico capaz de expressar precisamente o conteúdo conceitual do estabelecimento da paternidade: "mater semper certa est, pater autem incertum", que significa que "a mãe é sempre certa, no entanto, o pai é incerto". Com relação à maternidade não existem muitas dúvidas se comparada à paternidade. Porque afinal, o parto é um ato natural. Todavia, o presente trabalho pretende ir além da já elencada importância do estabelecimento da filiação e identificação dos progenitores, conclui-se, portanto, que não apenas qualquer pai, não apenas qualquer mãe. Ora se o número de pais for limitado, sua identidade não será mais indiferente. Visto que a verdade biológica tem uma influência importante sobre a ascendência legal, ela deve, em princípio, ser estabelecida em relação aos procriadores. Legisladores e juízes, portanto, muitas vezes relutam em estabelecer um vínculo entre a criança e as pessoas que não estiveram envolvidas em sua concepção (GARRIGUE, 2018), tudo com vistas à formalização de parentesco que esteja de acordo com a realidade genética.

O porvir vem se revelando potente nesse sentido, propiciando através da identidade genética que alarga ainda mais a noção de família. Portanto, e com essa dimensão simbólica da ancestralidade, o ser humano como ser-no-mundo procura se apropriar daquilo que o projeta para novas possibilidades, porém, tendo sempre em vista tudo aquilo que o alicerça. Ou seja, para se lançar a novos horizontes vê a necessidade de buscar explicações, de entender todos os fundamentos de seu ser, e isso perpassa seus ancestrais.

\section{Referências}

Araújo, P. C. de. (2017). Familysearch e familysearch indexing: Informação Genealógica Aberta Disponível na Internet. Ciência Da Informação Em Revista, $4(3), 12-24$.

Arquivo Nacional. (2009). Acordo de cooperação técnica processo $n^{o}:$ 320.000124/2009-19.

Bauman, Z. (2001). Modernidade líquida. Editora Schwarcz-Companhia das Letras. 
Research, Society and Development, v. 11, n. 2, e53611226218, 2022

Campos, D. L. de. (2004). Nós: estudos sobre o direito das pessoas. Coimbra: Almedina.

Campos, D. L. de, \& Campos, M. M. (2018). Lições de direito da família (3ª ed.). Coimbra: Almedina.

Canal USP. (2020). DNA do Brasil . USP Talks.

Coelho, F. P., \& Oliveira, G. de. (2015). Curso de Direito da Família (5 a ed.). Coimbra: Coimbra Editora.

Conselho Nacional de Justiça. (2010). Provimento $n^{\circ}$ 12. Brasília - DF.

Costa, H. N. R. (2011). Marcadores genéticos de previsão de fenótipos em contexto forense. Universidade de Aveiro.

Dias, M. B. (2013). Manual de Direito das Famílias (9ª ed.). Thomson Reuters.

Duster, T. (2014). Ancestry testing and DNA: uses, limits--and caveat emptor. In Genetics as social practice: Transdisciplinary views on science and culture (pp. 59-71). Routledge.

e Silva, M. A. C., Nunes, K., Lemes, R. B., Mas-Sandoval, À., Amorim, C. E. G., Krieger, J. E., Mill, J. G., Salzano, F. M., Bortolini, M. C., da Costa Pereira, A., Comas, D., \& Hünemeier, T. (2020). Genomic insight into the origins and dispersal of the Brazilian coastal natives. Proceedings of the National Academy of Sciences of the United States of America, 117(5), 2372-2377. doi: 10.1073/pnas.1909075117

Engels, F. (1884). A Origem da Família, da Propriedade Privada e do Estado.

Escobar, H. (2019). Cientistas querem desvendar receita genética do povo brasileiro. Jornal Da USP.

Fenouillet, D. (2014). La parentalité, nouveau paradigme de la famille contemporaine? Paris: Dalloz.

Garrigue, J. (2018). Droit de la famille. Paris: Dalloz.

Gaspar Neto, V. V., \& Santos, R. V. (2011). Biorrevelações: testes de ancestralidade genética em perspectiva antropológica comparada. Horizontes Antropológicos, 17(35), 227-255. doi: 10.1590/s0104-71832011000100008

Governo do Estado de São Paulo. (2015). Termo de Convênio - Processo no ${ }^{\circ}$ CC/150152/2015.

Heidegger, M. (2007). Ser e Tempo (Trad. Marcia Sá Cavalcante Schuback (ed.); 2a edição). Petrópolis: Editora Vozes.

Ipsos. (2021). GLOBAL PERCEPTIONS OF THE IMPACT OF COVID-19.

Lacan, J. (2008). Os complexos familiares na formação do indivíduo: ensaio de análise de uma função em psicologia. Zahar.

Marchesini Stival, S. L. (2020). Genética recreativa: os testes genéticos direct-to-consumer em Portugal. CADERNOS IBERO-AMERICANOS DE DIREITO SANITÁRIO, 9(3), 123-152. doi: 10.17566/ciads.v9i3.655

Mendes, M., Alvim, I., Borda, V., \& Tarazona-Santos, E. (2020). The history behind the mosaic of the Americas. Current Opinion in Genetics \& Development, 62, 72-77. doi: 10.1016/j.gde.2020.06.007

Ministério da Saúde. (2020). Portaria no 1.949 de 4 de Agosto de 2020.

MPPR. (2021). Direito de Família - Averiguação e Investigação de paternidade . Ministério Público Do Paraná.

Oliveira, G. de. (2018). Estabelecimento da Filiação. Coimbra: Petrony.

Patrinos, G. P., Pasparakis, E., Koiliari, E., Pereira, A. C., Hünemeier, T., Pereira, L. V., \& Mitropoulou, C. (2020). Roadmap for Establishing Large-Scale Genomic Medicine Initiatives in Low- and Middle-Income Countries. American Journal of Human Genetics, 107(4), 589-595. doi:

10.1016/j.ajhg.2020.08.005

Santos, E. dos. (1999). Direito da Família (2a ed.). Coimbra: Almedina.

Santos, Fabrício R. (2016). A grande árvore genealógica humana. Revista Da Universidade Federal de Minas Gerais, 21(1.2), 1689-1699. doi: $10.35699 / 2316-770 X .2014 .2643$

Santos, Fabricio R, Bianchi, N. O., \& Pena, S. D. (1996). Worldwide distribution of human Y-chromosome haplotypes. Genome Research, 6(7), 601-611. Siep, L. (2016). GWF Hegel: Grundlinien der Philosophie des Rechts (Vol. 9). Walter de Gruyter GmbH $\backslash \&$ Co KG.

Souza, S. M. de. (2011). Dispersão de Homo sapiens e povoameno dos continentes. In Fundamentos da paleoparasitologia (pp. 69-92).

Toffler, A. (1980). A terceira onda. Record.

Tribunal de Justiça do Rio Grande do Sul. (2008). Processo Administrativo SPI n020450-0300/01-7. 31.Autorização para Microfilmagem de Registro Civil de Nascimentos, Casamentos e óbitos pela Sociedade Genealógica de Utah (p. 218). Porto Alegre. 